\title{
KONSERVE HİNDİ SOSİS ÜRETİMİNDE ISIL İŞLEM VE DEPOLAMA SÜRESINIIN BAZI KALİTE ÖZELLİKLERİ ÜZERİNDEKİ ETKİSİ
}

\author{
Selen Akbulut ${ }^{1 *}$, Hakan Kuleaşan ${ }^{2}$ \\ ${ }^{1}$ Üsküdar Üniversitesi, Sağlık Hizmetleri Meslek Yüksekokulu, Gıda Teknolojisi Programı, İstanbul/ Türkiye \\ 2Süleyman Demirel Üniversitesi, Mühendislik Fakültesi, Gıda Mühendisliği Bölümü, Isparta, Türkiye
}

Geliş / Received: 30.09.2021; Kabul / Accepted: 27.01.2022; Online bask1 / Published online: 22.02.2022

Akbulut, S., Kuleaşan, H. (2022). Konserve hindi sosis üretiminde 1sıl işlem ve depolama süresinin bazı kalite özellikleri üzerindeki etkisi. GIDA (2022) 47(2) 157-168 doi: 10.15237/gida.GD21128

Akbulut, S., Kuleaşan, H. (2022). Konserve hindi sosis üretiminde ısıl işlem ve depolama süresinin bąı kalite özellikleri üzerindeki etkisi. GIDA (2022) 47(2) 157-168 doi: 10.15237/gida.GD21128

\section{Öz}

Bu çalışmada, koruyucu katkı maddesi kullanmaksızın hindi etinden üretilen sosislere $118{ }^{\circ} \mathrm{C}$ 'de 50 dakika sterilizasyon uygulanarak, 4 aylık depolama süreci boyunca mikrobiyolojik bozulmanın önlenmesi ve genel kalitenin korunması amaçlanmıştır. Çalışmada konserve sosis üretiminde kullanılan çiğ hindi etinin başlangıç bakteri yükü 4.33 log kob/g olarak tespit edilmiştir. Isıl işlem sonrasında raf ömrü boyunca sosis örneklerinde mikrobiyolojik bir gelişmenin tespit edilmemiş olması, ürüne uygulanan 1sıl işlemin etkin bir şekilde sterilizasyon sağlamış olduğunu göstermiştir. Oksidasyon derecesinin belirlendiği tiyobarbitürik asit (TBA) analizinde ise, hindi sosislerinde istatistiksel olarak fark görülmemiştir $(P>0.05)$. Bu çalışma, sıcak dolum ve etkin bir 1sıl işlem ile üretilen hindi sosislerinin koruyucu katkı kullanılmaksızın raf ömrü süresince sağlıklı bir şekilde korunabileceğini göstermiştir.

Anahtar kelimeler: Konserve et ürünleri, sterilizasyon, antimikrobiyal katkı maddesi, raf ömrü

\section{THE EFFECT OF HEAT TREATMENT AND STORAGE TIME ON SOME QUALITY PROPERTIES IN PRODUCTION OF CANNED TURKEY SAUSAGE}

\begin{abstract}
The aim of this work was prevention of microbiological deterioration while maintaining overall quality during 4-month storage period by sterilizing the sausages produced from turkey meat at 118 ${ }^{\circ} \mathrm{C}$ for 50 minutes without using preservatives. The initial bacterial load of raw turkey meat used in the production of canned sausage was determined as $4.33 \mathrm{log} \mathrm{cfu} / \mathrm{g}$. The fact that no microbiological development has been detected in sausage samples during the shelf life as a result of the applied heat treatment indicates that the heat treatment is performed effectively. In the Thiobarbituric acid analysis (TBA) in which the degree of oxidation was determined, there was no statistically significant difference in turkey sausages $(P>0.05)$. This study demonstrated that turkey sausages produced with hot filling along with an effective heat treatment can be preserved in a healthy way throughout their shelf life without the use of preservatives.
\end{abstract}

Keywords: Canned meat product, sterilization, antimicrobial additives, shelf life

${ }^{*}$ Yazışmalardan sorumlu yazar / Corresponding author;

$\triangle$ selen.akbulut@uskudar.edu.tr (c) (+90) 5466880598

盀 (+90) 2164002222

Selen Akbulut; ORCiD no: 0000-0003-3123-3010

Hakan Kuleaşan; ORCiD no: 0000-0002-0893-0689 


\section{GİRİ̧̧}

Kanatlı etleri içerisinde hindi eti, kolestrol seviyesinin düşük olması ve protein oranının yüksek olması nedeniyle sağlık açısından tercih edilmektedir (Koyubenbe ve Konca, 2010). 2020 yllında Gıda, Tarım ve Hayvancilık Bakanlığ Tarımsal Ekonomi ve Politika Geliştirme Enstitüsü tarafindan yayınlanan hindi eti üretim ve tüketim verileri incelendiğinde 2018 yllında kişi başı hindi eti tüketimi en yüksek seviyeye ulaşarak $700 \mathrm{~g} /$ yll olarak belirlenirken 2020 yllında bu oran $590 \mathrm{~g} / \mathrm{yll}$ olmuştur. Rapor incelendiğinde ABD ve diğer Avrupa ülkelerinde tüketim oranlarının yüksekliği görülmektedir (TEPGE, 2020)

Sosis; sığır, koyun, kanatlı etleri ve yağlarından emülsiyon tekniğinin kullanilması ile oluşturulan hamurun doğal veya yapay kiliflara doldurulup 1sil işlem uygulanması sonucu elde edilen et ürünüdür (Urgu, 2013). Geleneksel tarzda bir sosis üretim basamakları kısaca; et seçimi, parçalama ve karıştırma, emülsifiye etme, bağırsaklara doldurma, ön kurutma, dumanlama, haşlama/pişirme, soğutma, ambalajlama ve depolamadır (Anar, 2012).

Sosis üretim süreci içerisinde kullanılan katk1 maddelerinin başında gelen nitritler ve nitratlar, işlenmiş et ürünlerinde kalite ve mikrobiyolojik güvenlik üzerindeki olumlu etkileri ve ürünlerde antimikrobiyel, antioksidan ve istenen tipik pembe-kırmızı renk oluşumu gibi amaçlar için kullanilan maddelerdir (Anar, 2012). Ancak emülsifiye et ürünlerinde kullanılan nitrit-nitratın metabolize edilmesiyle nitrozamin bileşiklerinin oluşumu söz konusudur. 2015 yllında Dünya Kanser Araştırma Fonu (IARC) tarafindan yayınlanan raporda, kolorektal kanser oluşumu ile kırmızı et ve işlenmiş et ürünleri arasındaki ilişki gösterilmiştir. Bu ürünlerdeki nitrit kullanımının doğrudan toksisite ve kanserojen $\mathrm{N}$-nitrozamin oluşumuna katılımı nedeniyle işlenmiş et ve et ürünleri Grup 2A (insan için muhtemel kanserojenik) sınıfinda yer almıştır (IARC, 2015; Gültekin ve Akın, 2019).

Konserve işlemi, hermetik olarak kapatılmış gidaların içerisinde patojen veya bozulmaya neden olabilecek bütün mikroorganizmaların inhibe edilmesi amaciyla $100{ }^{\circ} \mathrm{C}$ ve üzeri sicaklık uygulanması şeklinde yapılan bir 1 sıl işlemdir. Konserve işleminin amac1, mikrobiyal populasyonun (vejetatif hücreler/sporlar) veya etin bozulmasindan sorumlu enzimlerin inhibisyonunu sağlamaktır (Hui vd., 2001; Toldrà, 2010; Özdikmenli ve Zorba, 2015).

Günümüzde yurtdışında yaygın bir tüketimi olan ancak ülkemiz gida piyasasında bulunmayan koruyucu ilavesiz konserve sosisin tüketicinin ilgisini ve beğenisini çekeceği düşünülmektedir. Ayrıca bu çalışma da, et endüstrisindeki alternatif ürün arayışına da yeni bir fikir sunması nedeniyle önem taşımaktadır.

Çalışmanın amacı, koruyucu herhangi bir katkı maddesi kullanılmaksızın üretilmiş konserve sosislerin raf ömrünü sağliklı bir şekilde korumaktır. $\mathrm{Bu}$ amaçla kimyasal koruyucular yerine 1 sıl işlem uygulanmış ve sosislerin bu şekilde raf ömrü boyunca korunması hedeflenmiştir. Çalışma kapsamında uygulanan bu termal koruma prosesinin, sosis örneklerinin kimyasal ve mikrobiyolojik özellikleri üzerine etkileri araştırılmıştır.

\section{MATERYAL VE YÖNTEM}

\section{Materyal}

Konserve hindi sosis üretiminde kullanılan hindi gögüs eti, hayvansal yağ, nişasta ve tuz yerel bir marketten paketlenmiş olarak temin edilmiştir. Baharat karışımını oluşturan her bir bileşen ise Isparta'da bulunan bir aktardan temin edilmiştir. Çalışmada kullanılan sosis kılıfları (Edicas,19NB, İspanya) saf fibrinojenden üretilmiş olup internet üzerinden satın alınmıştır. Çalışma kapsamında sosis üretimi Süleyman Demirel Üniversitesi Gıda Mühendisliği Bölümü'nde gerçekleştirilmiştir.

\section{YÖNTEM}

\section{Sosis üretimi}

Sosis üretimi için yaygin olarak tercih edilen bir sosis formülasyonu kullanılmıştır (Göğüş, 1986; Anar, 2012). Deneme üretimleri ve uygulanan 1s1 işlemler sonucunda, ürün nitelikleri olarak en başarılı sonuç alınan formülasyon ve sıcaklık/süre kullanılarak konserve işlemi gerçekleştirilmiş ve ürünler depolamaya alınmıştur. Çizelge 1'de sosis ürünü için üretimde kullanılan temel formülasyon bileşenleri verilmiştir. 
Çizelge 1. Hindi Sosis Ürün Bileşimi

Table 1. Turkey Sausage Product Composition

\begin{tabular}{lc}
\hline Bileşenler/ Ingredients & Kullanım Miktarl (g) / Amount of usage \\
\hline Hindi Göğüs Eti/ Turkey breast meat & $1000 \mathrm{~g}$ \\
\hline Hayvansal Yağ/ Animal Fat & $200 \mathrm{~g}$ \\
\hline Buz/ Ice & $300 \mathrm{~g}$ \\
\hline Nişasta / Strach & $50 \mathrm{~g}$ \\
\hline Tuz / Salt & $20 \mathrm{~g}$ \\
\hline Baharat Karışımı / Spice Mix & $15 \mathrm{~g}$ \\
\hline *Baharat karışım: \%0.1 kırmızıbiber, \%0.2 karabiber, \%0.1 kişniş, \%0.05 zencefil \\
* Spice Mix: \%0.1 red pepper, \%0.2 black pepper, \%0.1 coriander, \%0.05 ginger
\end{tabular}

Sosis üretiminde $+4^{\circ} \mathrm{C}^{\prime}$ de soğutulmuş taze hindi gögüs eti kullanılmıştır. Sosis üretim akım şeması ise, Şekil 1'de verilmiștir. Üretimin ilk basamağında hindi göğüs eti parçalama makinesinde kıyma haline getirilmiş ve hayvansal yağ ile kullanilacak olan buzun yarısı homojen bir hamur oluşuncaya kadar karıştırlmıştır. Belirlenen bileşenler ve kalan buz, hamura ilave edilerek homojen dağılımlı sosis emülsiyonu oluşturulmuştur. Sosis hamuru sığır kolojeninden üretilmiş tüketilebilir sosis k1lıflarına (Edicas,19NB, İspanya) mekanik yolla doldurulmuştur. Dolumu tamamlanan sosislerin dış kısımları yıkanmış ve kavanozlara (300 ccmetal kapakli, cam kavanoz) yerleştirilmiştir. Ardından kavanozların içerisine \%8-10 tepe boşluğu kalacak şekilde salamura $\left(85^{\circ}-90^{\circ} \mathrm{C}\right.$ 'de $\% 2 \mathrm{NaCl}$ ) eklenmiş ve kapakları kapatılmıştır. Sosis kavanozlar1 otoklava (ALP, Japonya) yerleştirilmiş ve belirlenen sıcaklık-sürede (118 ${ }^{\circ} \mathrm{C}-50$ dakika) 1sıl işlem uygulanmıştır. Isıl işlem sonrası kavanozlar soğutulmuş ve oda sıcaklığında depolamaya alınmıştır. Depolama periyodu boyunca, sosis örneklerine 0,30,60,90 ve 120 . günlerde analizler uygulanmıştır. Dolumu yapılmış ve ısıl işlem uygulanmış konserve hindi sosis örneğine ait görsel, Şekil 2' de verilmiştir.

\section{Isıl işlem parametrelerinin belirlenmesi ve hesaplanmış değerlerin sınanması}

Konserve sosis üretiminde, isıl işlem parametrelerinin belirlenmesi amaciyla farklı pek çok sıcaklık ve süre ürün geliştirme sürecinde denenmiştir. Başlangıç termofilik bakteri sporu yükü çiğ et içerisinde maksimum $10^{1}-10^{2} \mathrm{kob} / \mathrm{g}$ olma ihtimaline karşın denemelerde $10^{5} \mathrm{kob} / \mathrm{g}$ olabileceği varsayılarak hesaplamalar yapılmıştır.
Isıl işlem hesaplamalarında referans olarak 1sıl işlemlere en dayanıklı olarak kabul edilen Bacillus stearothermophilus sporlarına ait 1 sil işlem parametreleri $\left(\mathrm{D}_{121}=6.16\right.$ dakika, $\mathrm{z}$ değeri ise 8.3 ${ }^{\circ} \mathrm{C}$ saf suda) baz alınmıștır (Fraiha et al., 2010). Buradan uygulanması gereken minimum 1 sıl işlem değeri $\left(\mathrm{F}_{0}\right) \quad 121,11{ }^{\circ} \mathrm{C}$ 'de 30,8 dakika olarak bulunmuştur. $118{ }^{\circ}{ }^{\circ}$ 'deki $\mathrm{F}$ değerinin hesaplanmasinda:

$\mathrm{F}_{\mathrm{T}}=\mathrm{D}_{\mathrm{T}} \mathrm{S}_{\mathrm{D}}$

$\mathrm{F}_{118}=\int_{0} \mathrm{t} 10^{(\mathrm{T}-\mathrm{Tree}) / \mathrm{z}} \times \mathrm{t}$

' $\mathrm{D}_{\mathrm{T}}$ Isıl işlemde hedef alınan mikroorganizmanın T sıcaklıktaki D değeri', ' $\mathrm{S}_{\mathrm{D}:}$ Sterilizasyon Değeri', 'T: ürüne uygulanan sicaklik derecesi', ' $\mathrm{T}_{\text {ref: }}$ Referans sicaklik genellikle $250 \mathrm{~F}$ veya $121^{\circ} \mathrm{C}$ ', 'z: z-değeri', 't: süre' formülleri kullanılmıstır (Cemeroğlu, 2010).

Isıl işlem uygulaması sonucu üretilen ürünlerde, 1sıl işlemin etkinliğini belirlemek amaciyla konserve edilmiş ürünlerde ekimler (toplam mezofilik aerobik mikroorganizma sayımı) yapılmıştır. Gerçekleştirilen deneme üretimlerinde hiçbir mikrobiyel üremenin görülmediği parametreler baz alınarak $118^{\circ} \mathrm{C}$ 'de 50 dakika isıl işlem uygulanmıştır. Son ürüne uygulanan sıcaklık süre kombinasyonu için $\mathrm{F}$ değeri hesaplanmıştır.

\section{Analiz Yöntemleri}

Çalışma kapsamında, hammadde olarak kullanılan et örneğinde, sosis üretiminde kullanılan emülsiyon hamurunda üretim esnasinda ve üretimi gerçekleştirilen konserve sosis örneklerinde $0,30,60,90,120$. günlerde analiz işlemleri gerçekleştirilmiştir. 


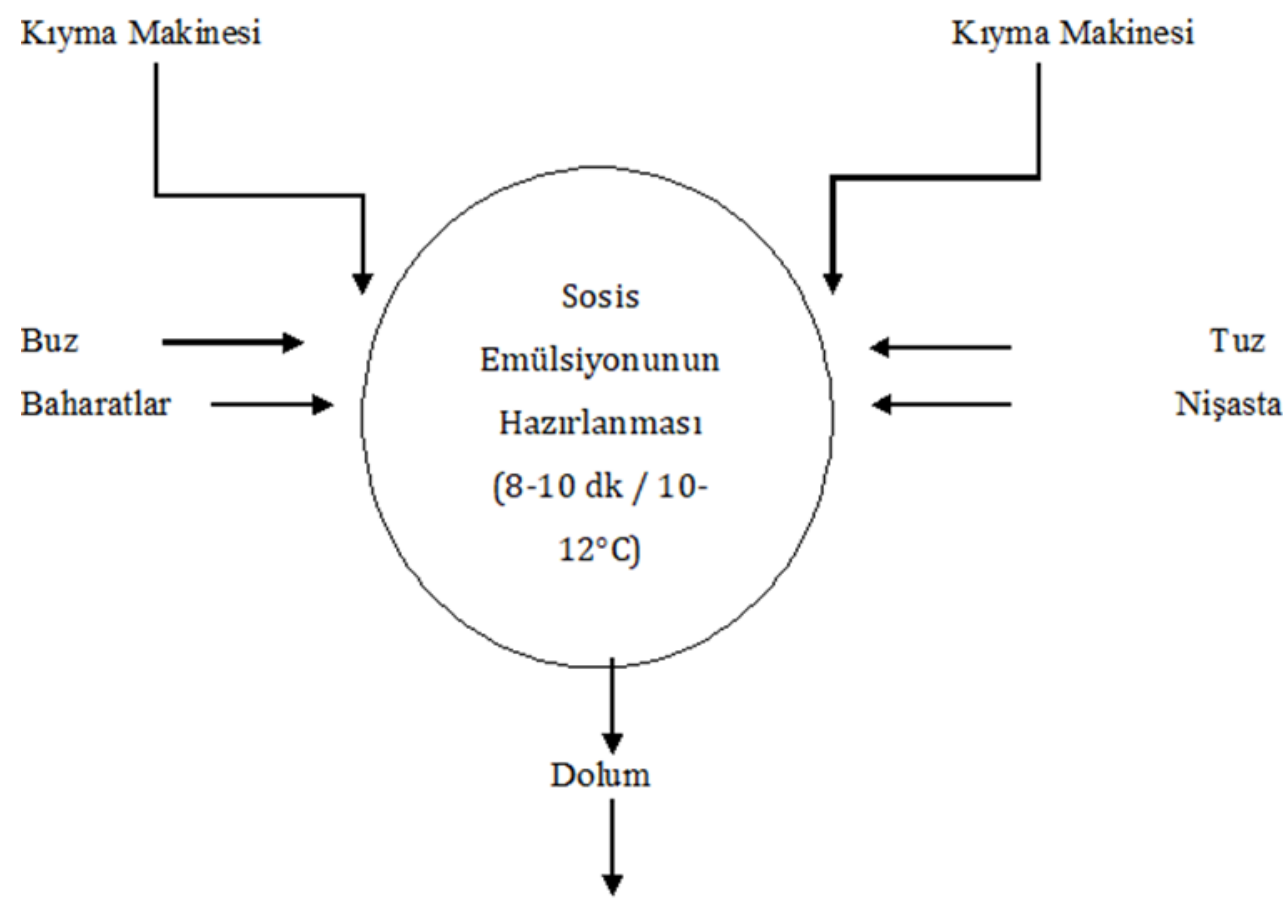

Sosislerin Y 1 kanması

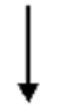

Kavanozlara Yerleştirme

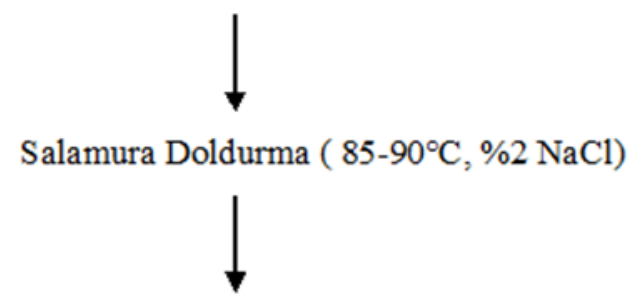

Sterilizasyon $\left(118^{\circ} \mathrm{C} / 50 \mathrm{dk}\right)$<smiles>CCCC</smiles>

Depolama

Şekil 1. Sosis Üretim Şemas1

Figure 1. Sausage Production Scheme 


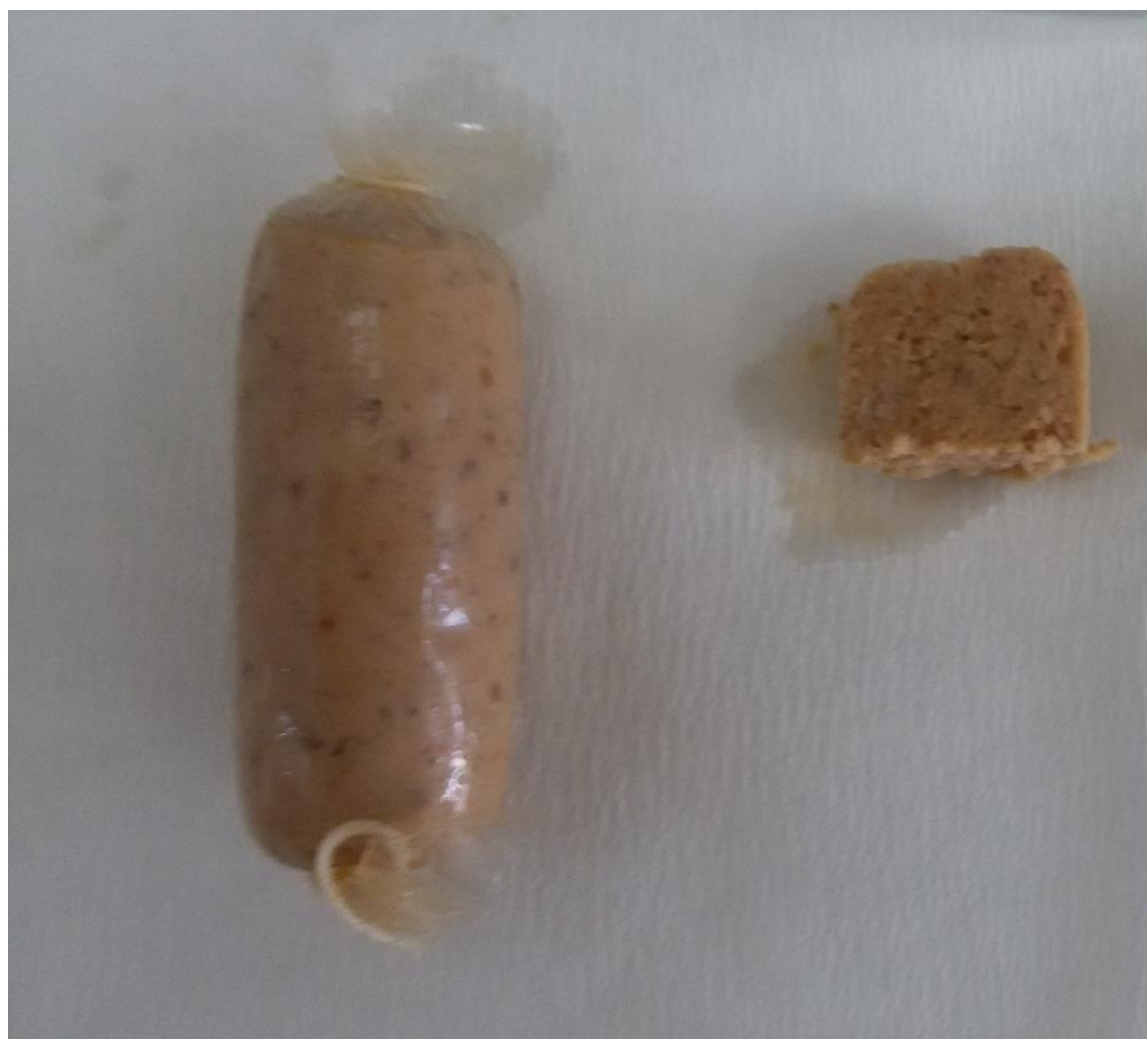

Şekil 2. Hindi Sosis Örneği

Figure 2. Turkey Sausage Example

\section{pH ölçümü}

Çalışmada hazırlanan örneklerin $\mathrm{pH}$ ölçümleri oda sicaklığında $\mathrm{pH}$ metre (InoLab, $\mathrm{pH}$ Level 1Prob tipi: Daldırmalı, Almanya) ile gerçekleştirilmiştir (Kayaardı vd., 2014).

\section{Yağ tayini}

Örneklerin içerdiği \% yağ miktarı Soxhlet ekstraksiyon yöntemi kullanılarak tespit edilmiştir. Analiz $5 \mathrm{~g}$ sosis örneğinde gerçekleştirilmiştir. Çözgen olarak dietil eter kullanılmıştır (Toptanc1, 2007; Şimşek, 2011).

\section{Toplam asitlik tayini}

AOAC (2000), metoduna uygun olarak $0.1 \mathrm{M}$ $\mathrm{NaOH}$ ile fenolftalein indikatörlüğ̈̈nde titrasyon ile gerçekleştirilmiştir. Sonuçlar \% laktik asit/g cinsinden toplam asitliği ifade etmektedir.

\section{Toplam kuru madde (nem) tayini}

Çalışmada, 5 g örnek, daha önce $105^{\circ} \mathrm{C}$ 'de kurutulmuş ve darası alınmış kaplara tartıldıktan sonra $125^{\circ} \mathrm{C}$ 'deki etüvde (Daihan, WiseVen, Güney Kore) sabit ağırllğa gelinceye kadar kurutulmuştur. Nem içeriği, ağırlık kaybından yüzdesel olarak hesap edilmiştir (Kayaardı vd., 2014).

\section{Tuz (Mohr Yöntemi) tayini}

Konserve sosis örneklerine belirlenen periyotlarda tuz tayini, Mohr yöntemi esas alınarak uygulanmıştır. Analizde $10 \mathrm{~g}$ konserve sosis örneği kullanılmış potasyum kromat indikatörlüğünde gümüş nitrat ile titrasyon yapılmıştır (Gökalp vd., 1993).

\section{Renk analizi}

Sosis örneklerinin kesit alanlarında ve dış yüzeylerinde, renk analizi cihazı (Minolta Chromameter, Japonya) ile ölçümler yapılmıştır. Örneklere renk analizi depolamanın 60. gününde gerçekleştirilmiştir. Ölçümler sonucunda örneklerin CIE $L^{*}, a^{*}, b^{*}$ değerleri kaydedilmiştir. ' $L^{*}$ parlaklık (0'dan 100'e), 'a*' yeşillik/kırmızılığ1 
(-60'dan +60 'a), ' $b$ *' ise mavilik/sarllı̆g (-60'dan +60'a) sarılık değerini göstermektedir (Kayaard1 vd., 2014; Turp vd., 2016).

\section{Tiyobarbitürik asit (TBARS) analizi}

Örneklerde lipid oksidasyon derecesini belirlemek amaciyla tiyobarbitürik asit (TBA) analizi yapılmıştır. Analiz için, $2 \mathrm{~g}$ sosis örneğinden alınıp daha sonra örnek üzerine $12 \mathrm{ml}$ TCA eklenerek homojenizatör yardımıla homojenize edilir. Homojenize edilen örneklerin Whatman no 1 filtre kâğıdı koyulmuş hunilerle süzülmesi sağlanmıştır. Süzüntüden $1 \mathrm{ml}$ alınarak üzerine 1 ml TBA çözeltisi eklenmiştir. Şahit (kör) çözelti için deney tüpü içerisine $1 \mathrm{ml}$ TCA ve $1 \mathrm{ml}$ TBA çözeltilerinden koyulmuştur. Tüpler bu halde vortekslenip, 40 dakika $100{ }^{\circ} \mathrm{C}$ su banyosunda bekletilmiştir. Tüpler 5 dakika süre ile musluk suyunda soğutularak falkon tüplerine aktarllmış ve 4100 devirde 10 dakika santrifüjlenmiştir. Süpernatantı alınan örnek, spektro küvetlerine koyularak $532 \mathrm{~nm}$ dalga boyunda spektrofotometrede (Shimadzu, UV-1601) okuma yapılmıştır (Şimşek, 2011; Texas Tech University, 2015).

\section{Mikrobiyolojik Analizler}

Mikrobiyolojik analizlerden; koliform grubu, maya-küf, toplam mezofilik aerobik bakteri, laktik asit bakterilerinin sayımı gerçekleştirilmiştir. Sosis örneklerinin (25 g örnek) ekimleri 10-1 dilüsyondan yapılırken salamura örneklerine dilüsyon yapilmamış steril bir şekilde konserve kavanozundan alınmıştır. Koliform grubu mikroorganizmaların analizi için Eosin Metile Blue agar (EMB-Merck, Almanya), maya-küf sayımı için ise Potato Dextrose Agar (PDA, Merck, Almanya) kullanılmıştır. Toplam mezofilik aerobik bakteri Plate Count Agar (PCA Merck, Almanya), laktik asit bakterilerinin sayımı De Man-Rogosa-Sharpe Agar (MRS-Merck, Almanya) besiyerlerinde yapılmıştır. Konserve sosis örneklerinde anaerop mikrobiyel gelissimin kontrolü için Plate Count Agar (Merck, Almanya)'a ekimler yapılmıştır. Anaerop ortamın hazırlanmasında, anaerobik jar içerisinde Anaerocult ${ }^{\circledR}$ C (Merck, Almanya) anaerobik ortam kiti kullanılmıştır. PCA ve MRS besiyerlerine yapilan ekimler, $30^{\circ} \mathrm{C}$ 'de 2 gün inkübe edilirken, $\mathrm{PDA}$ besiyerine $25^{\circ} \mathrm{C}$ 'de 5 gün, $\mathrm{EMB}$ besiyerine ise $37^{\circ} \mathrm{C}$ 'de 2 gün boyunca inkübasyon uygulanmıştır (Kayaardı vd., 2014).

\section{Tekstür profil analizi}

Tekstür profil analizi, (Urgu, 2013) yöntemine göre, konserve sosis örneklerinde Texture Analyzer (XTPlus; Stable Micro Systems, Godalming, İngiltere) cihazıyla yapılmıştır. Sosis örneklerine tekstür analizi depolamanin 60.gününde yapılmıştır. Analiz $50 \mathrm{~mm}$ çapındaki silindir baskı plakası altında; baskılama oranı 15 $\mathrm{mm}$, baskılama test hızı $3 \mathrm{~mm} / \mathrm{sn}$, geri çekilme test hızı $5 \mathrm{~mm} / \mathrm{sn}$ olarak uygulanmıştır. $5 \mathrm{~kg}$ yük hücresi kullanılmıştır. Analizde sertlik (hardness), yapışkanlık (addhesiveness), elastikiyet (springiness) ve çiğnenebilirlik (chewiness) doku parametreleri esas alınmıştır.

\section{İstatistiksel analiz}

Analizler sonucu elde edilen bulgular, istatistiksel olarak değerlendirilmiştir. Analiz sonuçlarının değerlendirilmesinde tek yönlü varyans analizi tekniği (ANOVA) ile TUKEY çoklu karşılaştırma testi kullanılmıştır. Deneme deseninde tekrarlanan faktör depolama süresi ( 0,30,60,90 vc 120 gün ) alınırken, sabit faktör birbirinin aynısı içeriğe sahip 3 tekerrür sosis örneği olarak kabul edilmiştir. Ortalamalar arasında istatistiksel olarak anlamlı farklar olup olmadığ $P \leq 0.05$ önem derecesinde belirlenmiştir.

\section{BULGULAR ve TARTIŞMA}

\section{Isıl İşlem Sonuçları ve $\mathrm{F}_{0}$ değeri}

Üretilen konserve sosis örneğine uygulanan $118^{\circ} \mathrm{C}$ isıl işlem için $\mathrm{F}$ değeri hesaplanmıştır. Konserve hindi sosis örneği için bu değer, 43.77 dakika bulunmuştur. Ancak mikrobiyel güvenliğin tam olarak sağlanması için 50 dakika olarak uygulanmıştır. Hedef olarak belirlenen $\mathrm{F}_{0}$ değeri baz alındığında uygulanan sterilizasyon işlemi ile 1s1l işlemde bir olumsuzluk olmadan steriliteye ulaşıldığı belirlenmiştir.

Hindi Eti, Emülsiyon Hamuru ve Sosis Örneklerine Uygulanan Analiz Sonuçları

Sosis üretiminde kullanilan hindi eti, emülsiyon hamuru ve sosis örneklerine ait kimyasal analiz sonuçları, Çizelge 2‘de verilmiş̧ir. 
Çizelge 2. Örneklere Uygulanan Kimyasal Analiz Sonuçları Table 2. Chemical Analysis Results Applied to Samples

\begin{tabular}{|c|c|c|c|c|}
\hline Örnekler/Samples & $\begin{array}{c}\mathrm{pH} \text { Analizi / } p H \\
\text { analysis }\end{array}$ & $\begin{array}{l}\text { Toplam Asitlik } \\
\text { Analizi/ Total } \\
\text { Acidity Analysis }\end{array}$ & $\begin{array}{l}(\%) \text { Nem / \% } \\
\text { Moisture }\end{array}$ & $\begin{array}{l}\text { Yağ Analizi } \\
\text { (Kurumaddede \%)/ Fat } \\
\text { Analysis (\% in dry matter) }\end{array}$ \\
\hline $\begin{array}{l}\text { Hindi Eti/ Turkey } \\
\text { Meat }\end{array}$ & $5.59 \pm 0.02$ & $0.022 \pm 0.003$ & $74.33 \pm 0.38$ & $1.32 \pm 0.05$ \\
\hline $\begin{array}{l}\text { Emülsiyon Hamuru } \\
\text { /Emulsion Paste }\end{array}$ & $5.54 \pm 0.07$ & - & - & - \\
\hline $\begin{array}{l}\text { 0.Gün Sosis Örneği } \\
\text { / o.Day Sausage } \\
\text { Sample }\end{array}$ & $5.61 \pm 0.01^{\mathrm{c}}$ & $0.023 \pm 0.003^{\mathrm{ab}}$ & $72.53 \pm 0.21^{\mathrm{ab}}$ & $7.79 \pm 0.76^{c}$ \\
\hline $\begin{array}{l}\text { 30.Gün Sosis } \\
\text { Örneği / 30.Day } \\
\text { Sausage Sample }\end{array}$ & $5.79 \pm 0.07^{b}$ & $0.016 \pm 0.001^{\mathrm{abc}}$ & $69.13 \pm 0.73^{b}$ & $9.98 \pm 0.84^{b}$ \\
\hline $\begin{array}{l}\text { 60.Gün Sosis } \\
\text { Örneği / 60.Day } \\
\text { Sausage Sample }\end{array}$ & $5.68 \pm 0.06^{\mathrm{bc}}$ & $0.025 \pm 0.070^{\mathrm{a}}$ & $71.39 \pm 1.77^{\mathrm{ab}}$ & $10.25 \pm 0.05^{b}$ \\
\hline $\begin{array}{l}\text { 90.Gün Sosis } \\
\text { Örneği / 90.Day } \\
\text { Sausage Sample }\end{array}$ & $5.78 \pm 0.02^{\mathrm{b}}$ & $0.013 \pm 0.003^{c}$ & $73.14 \pm 0.33^{\mathrm{a}}$ & $8.05 \pm 0.09 c$ \\
\hline $\begin{array}{l}\text { 120.Gün Sosis } \\
\text { Örneği / 120.Day } \\
\text { Sausage Sample }\end{array}$ & $6.20 \pm 0.05^{\mathrm{a}}$ & $0.014 \pm 0.001^{b c}$ & $74.16 \pm 2.51^{\mathrm{a}}$ & $13.10 \pm 0.26^{\mathrm{a}}$ \\
\hline
\end{tabular}

Çizelge 2 incelendiğinde, emülsiyon hamurunda $\mathrm{pH}$ değeri 5.57 tespit edilmiş olup, sosis örneklerinde depolama süresinde $\mathrm{pH}$ değeri düzenli olarak artmıştır. 120. günde $\mathrm{pH} \quad 6.20$ değerine kadar yükselmiş ve bu yükseliş istatistiksel olarak önemli bulunmuştur $(P<0.05)$. Hindi etleri üzerine farklı marinasyon uygulamalarının incelendiği bir çalışmada, çiğ hindi göğüs eti $\mathrm{pH}$ değeri 6.17 olarak tespit edilmiştir ( Ergezer, 2005).

Konserve sosis üretiminde kullanılan çiğ et örneğine ve sosis örneklerinde, depolama boyunca yapılan toplam asitlik tayini sonuçlarına ait bulgular \% laktik asit cinsinden, Çizelge 2'de verilmiştir. Konserve hindi sosis örnekleri arasındaki depolama boyunca farklılık istatistiksel olarak önemli bulunmuştur $(P<0.05)$.

Çiğ hindi eti örneği ve konserve sosis örneklerine ait toplam kuru madde sonuçları, incelendiğinde, sonuçlar arasındaki fark istatistiksel olarak önemli bulunmuştur $(P<0.05)$. Örneklerin \% nem oranlar1 \%69.13 ile \%74.33 arasında değişim göstermektedir.

Yağ analizi sonuçları incelendiğinde, çiğ hindi göğüs eti örneğinde $\%$ yağ değeri, $\% 1.32$ olarak tespit edilmiştir. Konserve hindi sosis örneğinde ise depolama boyunca en yüksek yağ değeri 120.depolama gününde $\% 13.10$ olarak belirlenmiş ve bu değer diğer depolama günlerinden istatistiksel olarak farklı bulunmuştur $(P<0.05)$.

Çiğ hindi eti ve konserve sosis örneklerinde depolama süreci boyunca meydana gelen mikrobiyolojik değişimleri incelemek amacıyla, sosis ve salamura örneklerine toplam aerobik mezofilik bakteri, toplam maya-küf, toplam koliform grup bakteri ve anaerob ortamda gelişen toplam mezofilik bakteri ekimleri 
gerçekleştirilmiştir. Sonuçlar Çizelge 3'te verilmiştir. Sonuçlar incelendiğinde, hindi eti ekim sonuçlarında toplam laktik asit bakteri sayım sonucu tespit edilebilir limitlerin altında $(<1)$ bulunurken, diğer ekimlerde mikrobiyal gelişim gözlemlenmiştir. Depolama süreci boyunca konserve sosis örneklerinde herhangi bir mikrobiyolojik gelişimin olmaması, uygulanan 1sıl işlemin etkin bir şekilde yapıldığını göstermektedir.

Nasser (2015) tarafindan, Suudi Arabistan'da satılan 13 farklı konserve et ürününün küf, mikrobiyolojik ve ağır metal içeriklerinin belirlendiği çalışmada, 13 konserve et ürününde, toplam bakteri, toplam koliform, toplam küf ve maya sayıları incelenmiş ve örneklerin büyük bir çoğunluğunda çalışmamızda olduğu gibi bakteriyel bir oluşum tespit edilmemiştir.
Sezen (2009), tarafindan İstanbul piyasasinda satışa sunulan 175 taze kanatlı eti numunelerinin, son kullanma tarihlerinde duyusal, kimyasal ve mikrobiyolojik analizleri yapılarak hijyenik kalitelerinin incelendiği çalışmada, hindi etlerinde mikrobiyal yük $4.5 \times 10^{5}-5.0 \times 10^{8} \mathrm{kob} / \mathrm{g}$, ortalama $6 \times 10^{7} \mathrm{kob} / \mathrm{g}$ bulunmuştur. Hindi eti örneklerinin \%66's1, Türk G1da Kodeksi limitlerinin üzerinde sonuç vermiştir.

Salcedo-Sandoval vd. (2015), tarafindan n-3 PUFA ile yağ içeriği zenginleştirilmiş frankfurter üretimi ve raf ömrü üzerine yapılan çalışmada, depolama ve formülasyondan dolay1 sosislerde mikrobiyel gelişim görülmüştür. Genel olarak toplam bakteri sayısı ve laktik asit bakteri sayıs arasinda (sırasiyla 3 ve $2 \log \mathrm{cfu} / \mathrm{kg}$ ) farklillk görülmediği, Enterobacteriaceae sayısının ise depolama süresi boyunca $<1 \log \mathrm{cfu} / \mathrm{kg}$ altında bir gelişim gösterdiği belirtilmiştir.

Çizelge 3. Hindi eti ve Sosis Örneklerine Uygulanan Mikrobiyolojik Ekim Sonuçları Table 3. Microbiological Analysis Results Applied to Turkey Meat and Sausage Samples

\begin{tabular}{|c|c|c|c|c|c|}
\hline $\begin{array}{l}\text { Örnekler/ } \\
\text { Samples }\end{array}$ & $\begin{array}{l}\text { TMAB }(\log \\
\mathrm{kob} / \mathrm{g})\end{array}$ & $\begin{array}{c}\text { Toplam } \\
\text { Maya-Küf } \\
(\log \text { kob/g) }\end{array}$ & $\begin{array}{c}\text { Laktik Asit } \\
\text { Bakterisi (log } \\
\text { kob/g) }\end{array}$ & $\begin{array}{l}\text { Toplam } \\
\text { Koliform } \\
\text { Sayis1 (log } \\
\text { kob/g) }\end{array}$ & $\begin{array}{l}\text { TMAB (Anaerob } \\
\text { ortam) (log kob/g) }\end{array}$ \\
\hline $\begin{array}{l}\text { Çiğ Et / Raw } \\
\text { Meat } \\
\text { 0.Gün Sosis }\end{array}$ & $4.33 \pm 0.33$ & $2.77 \pm 2.40$ & $<1$ & $1.90 \pm 1.65$ & - \\
\hline $\begin{array}{l}\text { Örneği / O.Day } \\
\text { Sausage Sample } \\
\text { 30.Gün Sosis }\end{array}$ & $<1$ & $<1$ & $<1$ & - & $<1$ \\
\hline $\begin{array}{l}\text { Örneği / 30.Day } \\
\text { Sausage Sample } \\
\text { 60.Gün Sosis }\end{array}$ & $<1$ & $<1$ & $<1$ & - & $<1$ \\
\hline $\begin{array}{l}\text { Örneği / 60.Day } \\
\text { Sausage Sample } \\
\text { 90.Gün Sosis }\end{array}$ & $<1$ & $<1$ & $<1$ & - & $<1$ \\
\hline $\begin{array}{l}\text { Örneği / 90.Day } \\
\text { Sausage Sample } \\
\text { 120.Gün Sosis }\end{array}$ & $<1$ & $<1$ & $<1$ & - & $<1$ \\
\hline $\begin{array}{l}\text { Örneği / } \\
\text { 120.Day Sausage } \\
\text { Sample }\end{array}$ & $<1$ & $<1$ & $<1$ & - & $<1$ \\
\hline
\end{tabular}

*Sonuçlar 2 paralel 3 tekerrürün ortalamasını ifade etmektedir.

*The results represent the average of 2 parallel 3 replications.

*TMAB: Toplam aerobik mezofilik bakteri sayısını, PCA (Anaerob): konservede gelişen toplam anaerobik canlı sayısını ifade etmektedir.

* TMAB: The total number of aerobic mesophilic bacteria, TMAB (Anaerobe): expresses the total number of anaerobic organisms grown in the can. 


\section{Konserve Hindi Sosis Örneğine Uygulanan} Analizler

Depolama süresince belirlenen periyotlarda hindi sosis örneklerinde belirlenen tuz miktarları ve TBARS analizi sonuçları Çizelge $4^{`}$ te $\mathrm{MDA} / \mathrm{kg}$ birimiyle verilmiştir.

Tuz miktarı incelendiğinde depolamanın ilk üç ayında sonuçlar arasında bir farklılık gözlenmezken $(P$ >0.05), 120. gün analiz sonuçları bu günlerden istatistiksel olarak farklı bulunmuştur $(P<0.05)$. FSA (Food Standards Agency, İngiltere)'nın et ürünlerinde kullanmak üzere belirlediği sodyum ve eşdeğer tuz seviyeleri incelendiğinde, sosisler ve konserve sosis için, 100 g porsiyonlarında $1.4 \mathrm{~g} \mathrm{NaCl}$ alımını önermişlerdir (Desmond, 2006).

Çizelge 4. \%Tuz ve TBARS Analiz Sonuçları

Table 4. \% Salt and TBARS Analysis Results

\begin{tabular}{|c|c|c|}
\hline Örnek/ Sample & $\%$ Tuz / \% Salt & $\begin{array}{l}\text { TBARS }(\mathrm{mg} \text { MDA } / \mathrm{kg}) / \\
\text { TBARS }(m g M D A / \mathrm{kg}) /\end{array}$ \\
\hline $\begin{array}{l}\text { 0.Gün Sosis Örneği / O.Day } \\
\text { Sausage Sample }\end{array}$ & $1.89 \pm 0.10^{\mathrm{b}}$ & $0.204 \pm 0.136 \mathrm{a}$ \\
\hline $\begin{array}{l}\text { 30.Gün Sosis Örneği / 30.Day } \\
\text { Sausage Sample }\end{array}$ & $2.12 \pm 0.02^{\mathrm{b}}$ & $0.202 \pm 0.166^{a}$ \\
\hline $\begin{array}{l}\text { 60.Gün Sosis Örneği / 60.Day } \\
\text { Sausage Sample }\end{array}$ & $1.90 \pm 0.22^{\mathrm{b}}$ & $0.195 \pm 0.084^{a}$ \\
\hline $\begin{array}{l}\text { 90.Gün Sosis Örneği / 90.Day } \\
\text { Sausage Sample }\end{array}$ & $2.08 \pm 0.25^{b}$ & $0.164 \pm 0.135^{a}$ \\
\hline $\begin{array}{l}\text { 120.Gün Sosis Örneği / } \\
\text { 120.Day Sausage Sample }\end{array}$ & $2.50 \pm 0.24^{a}$ & $0.185 \pm 0.081^{a}$ \\
\hline
\end{tabular}

Çizelge 4 incelendiğinde, TBARS değerlerinde depolama boyunca önemli bir fark belirlenmemiştir $(P>0.05)$. Depolama süresinde TBARS değerlerinde herhangi bir değişimin meydana gelmemesi, salamuranın sicak dolum yapılması ve ssıl işlem uygulamasıyla ortamdaki oksijeni uzaklaştırdığını ve oksidatif enzimlerin faaliyetlerini yavaşlattığını göstermektedir.

Ticari olarak satılan antioksidanların mekanik olarak ayrılmış hindi etindeki etkisinin incelendiği bir çalışmada, düşük konsantrasyonlarda kullanılan antioksidanların ilk 2 ay boyunca oksidasyon sürecini geciktirdiği ilerleyen süreçte ise daha fazla antioksidana ihtiyaç olacağ sonucuna varılmıştır. 7 aylık depolama boyunca antioksidan kullanilmayan hindi etindeki oksidatif değişim incelendiğinde, depolamanın ilk gününden itibaren oksidasyon değerinin arttığ1 görülmektedir (Mielnik vd., 2003).
Konserve sosis örneklerinde yapılan renk analizi sonucu elde edilen veriler dış yüzey ölçümleri ve iç yüzey ölçümleri olmak üzere Çizelge 5'te verilmiştir.

Çizelge 5. Renk Analizi Sonuçları Table 5. Color Analysis Results

\begin{tabular}{|c|c|c|}
\hline $\begin{array}{l}\text { Renk } \\
\text { Analizi/ } \\
\text { Color } \\
\text { Analysis }\end{array}$ & $\begin{array}{l}\text { Hindi sosis iç } \\
\text { kesit yüzeyi / } \\
\text { Turkey sausage } \\
\text { inner cross- } \\
\text { section }\end{array}$ & $\begin{array}{l}\text { Hindi sosis diş } \\
\text { yüzey / Turkey } \\
\text { sausage outer } \\
\text { cross-section }\end{array}$ \\
\hline $\mathrm{L}^{*}$ & $58.92 \pm 2.015$ & $61.35 \pm 0.768$ \\
\hline$a^{*}$ & $3.96 \pm 0.333$ & $1.25 \pm 0.420$ \\
\hline $\mathrm{b}^{*}$ & $15.25 \pm 1.160$ & $10.98 \pm 0.530$ \\
\hline
\end{tabular}

* Değerler 4 ölçümün ortalamasını ifade etmektedir.

* The results represent the average of 4 measurement. 
Konserve sosis örneklerinde gerçekleştirilen tekstür profili analizi kapsamında, sertlik (hardness), yapışkanlık (adhesiveness), elastikiyet (springiness) ve çiğnenebilirlik (chewiness) değerleri incelenmiş elde edilen sonuçlar Çizelge 6'da verilmiştir.

Çizelge 6. Tekstür Profili Analiz Sonuçları

Table 6. Texture Profile Analysis Results

\begin{tabular}{lcccc}
\hline Örnek/ Sample & $\begin{array}{c}\text { Sertlik } \\
\text { (bardness) }\end{array}$ & $\begin{array}{c}\text { Yapışkanlık } \\
\text { (adhesiveness) }\end{array}$ & $\begin{array}{c}\text { Elastikiyet } \\
\text { (springiness) }\end{array}$ & $\begin{array}{c}\text { Çiğnenebilirlik } \\
\text { (chewiness) }\end{array}$ \\
\hline $\begin{array}{l}\text { Hindi Sosis } \\
\begin{array}{l}\text { Örneği / Turkey } \\
\text { sausage sample }\end{array}\end{array}$ & $624.60 \pm 60.85$ & $-5.24 \pm 0.95$ & $1.02 \pm 0.02$ & $249.29 \pm 27.09$ \\
$\begin{array}{l}\text { *Değerler } 6 \text { ölçümün ortalamasını ifade etmektedir. } \\
\text { * The results represent the average of } 6 \text { measurement. }\end{array}$ & & \\
\end{tabular}

\section{SONUÇ}

Çalısmada emülsifiye et ürünlerinden biri olan sosisin, koruyucu katk1 kullanmaksızın yalnızca 1sil işlem uygulanarak raf ömrünü sağlıklı bir şekilde korumak hedeflenmiştir. Konserve sosis üretiminde kullanilan hammaddeden üretilen son ürüne kadar mikrobiyal faaliyetlerin belirlenmesi ve hedef mikroorganizmalar baz alınarak 1 sıl işlem parametrelerine uygun bir konserveleme işlemi gerçekleştirilmesi amaçlanmıştır. $\mathrm{Bu}$ doğrultuda sosis örneğine $118^{\circ} \mathrm{C}$ 'de 50 dakika isıl işlem uygulanmıştır. Uygulanan bu isıl işlem ile mikrobiyolojik sterilite sağlanmıştır.

Son yıllarda tüketicilerin bilinçlenmesi, katk1 maddelerinin gıda maddelerinde kullanımına dair endişelerin artması sonucu bu ürünlerin tercih edilirliğini azalmıştır. $\mathrm{Bu}$ bakımdan tüketiciler koruyucu madde içeren et ve et ürünleri yerine bunları içermeyen alternatiflerine yönelmişlerdir. Hem koruyucu katkı maddesi içermeyen hem de sterilitesi sağlanmış konserve sosis ürünü ülkemiz et endüstrisinde henüz üretilmemektedir. Ülkemizde et ürünlerine yönelik bir konserve ürün piyasasının bulunmayışı bu çalışmanın önemini arttırmaktadır. Et ve et ürünlerinin denetimsiz üretimlerinin oldukça yaygın olması, belirli limitler dâhilinde kullanımına izin verilen koruyucu katkı maddelerinin eğitilmemiş kişilerce emülsifiye et ve et üretimlerinde kullanımı tüketici sağllğını tehlikeye sokmaktadır.

Bu çalışma ileri dönemlerde farklı et ürünlerinin sterilizasyonu üzerine yapılacak çalışmalara bir temel sağlamak amaciyla gerçekleştirilmiştir.
Sterilizasyon tekniği ile üretilecek ürünlerde özellikle tekstürün iyileştirilmesi üzerinde daha derinlemesine çalışmalar yapilması gerekmektedir. Ayrica farklı ürünlerin de isıl işlem parametrelerinin belirlenmesine yönelik planlanacak çalsşmalar ülkemiz gida endüstrisine yarar sağlayacaktır.

\section{ÇIKAR ÇATIŞMASI BEYANI}

Yazarların, başka kişiler ve/veya kurumlar ile çıkar çatışması bulunmamaktadır.

\section{YAZAR KATKILARI}

Selen Akbulut deneylerin planlanmasi ile yapılışında görev almış ve taslak metni oluşturmuştur. Hakan Kuleaşan danışman olarak çalışma fikrinin oluşmasında, deney tasarımının oluşturulmasında, verilerin değerlendirilmesinde ve taslağın kontrolünde/düzenlenmesinde görev almıştır. Yazarlar makalenin son halini okumuş ve onaylamıştır.

\section{TEŞEKKÜR}

$\mathrm{Bu}$ çalışma, Süleyman Demirel Üniversitesi, Bilimsel Araştırma Projeleri Koordinasyon Birimi (Proje No: 4438-YL1-15) tarafindan desteklenmiştir.

\section{KAYNAKLAR}

Anar, S..(2012). Et ve Et Ürünleri Teknolojisi. Dora Yayınları, 410s, Bursa.

Association of Official Analytical Chemists, (2000). In:Official Methods of Analysis, 17th edition, Titratable acidity of fruit products, 942.15. AOAC International, Gaithersburg. 
Cemeroğlu, S,B. (2010). Gıda Mühendisliğinde Temel İşlemler, Gıda Teknolojisi Derneği Yayınlanı, 256s, Ankara.

Desmond, E. (2006). Reducing salt: A challenge for the meat industry. Meat Sci.74 (2006) 188-196, doi:10.1016/j.meatsci.2006.04.014

Ergezer, H. (2005). Değişik Yöntemlerle Marine Edilmiş Kanatlı Etlerinin Kimyasal, Mikrobiyolojik, Tekstürel ve Duyusal Özellikleri. Pamukkale Üniversitesi, Fen Bilimleri Enstitüsü, Yüksek Lisans Tezi, 101s, Denizli.

Gültekin, F., Akın, S. (2019). İşlenmiş Et Ürünleri ve Gıda Katk1 Maddeleri. Academic Platform Journal of Halal Lifestyle, 1 (1), 44-53. Retrieved from https://dergipark.org.tr/tr/pub/apjhls/issue/46 548/431903

Göğüş, K, A.(1986). Et Teknolojisi. Ankara Üniversitesi Ziraat Fakültesi Yayınları, Ankara, 242s.

Gökalp, Y., H., Kaya, M., Tülek, Y., Zorba, Ö. (1993). Et ve Ürünlerinde Kalite Kontrolü ve Laboratuvar Uygulama Kilavuzu, Atatürk Üniversitesi Ziraat Fakültesi Ofset Tesisi, 157s., Erzurum,140-146s.

Hui, Y.H., Nip,W.K.,Rogers,R.W., Young,O,A. (2001) . Meat Science and Application. Markel Dekker, 675s, New York.

IARC. (2015). IARC Monographs evaluate consumption of red meat and processed meat. Retrieved from . https://www.iarc.fr/en/mediacentre/pr/2015/pdfs/pr240_E.pdf

Kayaardı, S., Söbeli, C., Akkara, M.( 2014). Et Teknolojisi Laboratuarı El Kitabı. Sidaş Yayınları, Manisa, 83s.

Koyubenbe, N. \& Konca, Y. (2010). Türkiye ve Avrupa Birliği'nde Hindi Eti Üretimi, Tüketimi ve Politikaları. Ege Univ Ziraat Fak Derg, 47 (2) , 201209.

Mielnik, M. B., Aaby, K., Skrede, G. (2003). Commercial antioxidants control lipid oxidation in mechanically deboned turkey meat. Meat Sci. ,65(3), 1147-1155, doi:10.1016/S03091740(02)00345-5
Milford, A. B., Le Mouël, C., Bodirsky, B. L., \& Rolinski, S. (2019). Drivers of meat consumption. Appetite, 141, 104313, doi: 10.1016/j.appet.2019.06.005

Nasser, L. A. (2015). Molecular identification of isolated fungi, microbial and heavy metal contamination of canned meat products sold in Riyadh, Saudi Arabia. Saudi J Biol Sci. 22(5), 513520, doi:10.1016/j.sjbs.2014.08.003

Özdikmenli S,Zorba N. N (2015). Közlenmiş Kırmız1 Biber (Kapya) Konservesi Üretiminde Gıda Güvenliği. Tekirdă̆ Ziraat Fakültesi Dergisi, 12(1), 55 - 64.

Salcedo-Sandoval, L., Ruiz-Capillas, C., Cofrades, S., Triki, M., Jiménez-Colmenero, F. (2015). Shelf-life of n-3 PUFA enriched frankfurters formulated with a konjac-based oil bulking agent. LWT-Food Sci. Tech., 62(1), 711-717, doi:10.1016/j.lwt.2015.01.043

Sayari, N., Sila, A., Balti, R., Abid, E., Hajlaoui, K., Nasri, M., \& Bougatef, A. (2015). Antioxidant and antibacterial properties of Citrus paradisi barks extracts during turkey sausage formulation and storage. Biocatalysis and Agricultural Biotechnology, 4(4), 616-623, doi:10.1016/j.bcab.2015.10.004

Sezer, C.., Öğün, M., Güven, A. (2013). Salam ve Sosislerin Bazı Kimyasal Özelliklerinin İncelenmesi. Kafkeas Univ Vet Fak Derg, 19 (1),6972.

Şimşek, A. (2011). Tüketime Hazır Balık Döner Üretimi: Kimyasal, Mikrobiyolojik ve Duyusal Özelliklerinin Araştırılması. Süleyman Demirel Üniversitesi, Fen Bilimleri Enstitüsü, Yüksek Lisans Tezi, 156s, Isparta.

Texas Tech University. (2015). Thiobarbituric Acid Analysis (TBA). Erişim tarihi:03.07.2015 https://www.depts.ttu.edu/meatscience/docs/T hiobarbituricAcidAnalysis.pdf

TEPGE (2020). Hindi Eti. bttps:/ / arastirma.tarimorman.gov.tr . ( Erişim Tarihi: 08.11.2021)

Toldrä, F. (2010). Handbook of Meat Processing , Blackwell Publishing., 561s., USA. 
Toptanc1, İ.( 2007). Sucuğun renk ve tekstürüne farklı isıl işlem sıcaklıklarının etkisi. Ankara Üniversitesi, Fen Bilimleri Enstitüsü, Yüksek Lisans Tezi, 106s, Ankara.

Turp, G., Kazan, H., \& Ünübol, H. (2016). Sosis üretiminde doğal renk maddesi ve antioksidan olarak kırmızı pancar tozu kullanımı. CBU J. of Sci.,12(2).
Urgu, M. (2013). Yağ1 Azaltılmış Sosislerde Su içinde Findık Yağı Emülsiyonu ve Findık Tozu Kullanımının Araştırılması Tasarımı. Ege Üniversitesi Fen Bilimleri Enstitüsü, Yüksek Lisans Tezi, 135s, İzmir. 